Marini

\title{
El México que no fue: The Tentative Retelling of Luis Donaldo Colosio's Assassination
}

On the occasion of the 25th anniversary of his death in 2019, Netflix released two limited series focused on Mexican presidential candidate Luis Donaldo Colosio and his assassination. 1994 (directed by Diego Enrique Osorno) and Crime Diaries: The Candidate (Historia de un crimen: Colosio, directed by Hiromi Kamata and Natalia Beristáin) are, respectively, a documentary series and a drama, both delving into the political conjuncture surrounding both Colosio's candidacy and the investigations subsequent to his assassination. Since his dramatic death, the image of Colosio has maintained its associations with heroism and his unrealized presidency has come to embody the "México que no fue," a radically innovated Mexican state that never was and, possibly, will never be. Both series rely on the exploitation of original footage and underlying political takes on the events. This analysis will critically compare the two series from three main thematic perspectives: the Mexican political context at the time of the assassination; Colosio's characterization and private life; and the procedural aspects of the investigations.

Keywords

TV SERIES

MEXICAN SERIES

LUIS DONALDO COLOSIO

CRITICAL DISCOURSE ANALYSIS

NETFLIX

POLITICAL HISTORY

CRIME DRAMA

Date submitted: 08/09/2020

Date accepted: 17/03/2021

Anna Marta Marini

anna.marini@edu.uah.es

orcid.org/0000-0001-8268-2516

PhD fellow at the Instituto Franklin-UAH with a research project exploring the film representation of border crossing and otherness bridging the US-Mexico boundary, realized in codirection with the CISAN-UNAM. She specializes in US American and Mexican Studies and her main research interests are: critical discourse analysis related to institutional violence (either direct, structural, or cultural) and discrimination; discursive and cultural representation of the US-Mexico borderlands and Mexican American cultural heritage; identity re/construction and narration through cinema and comics related to minorities and otherness in gothic, horror, and (weird)western genres. 
On the occasion of the 25th

anniversary of his death in 2019, Netflix released two limited series focused on Luis Donaldo Colosio, a popular historical figure in the Mexican public imaginary. Chosen as the main candidate in the Mexican presidential elections of 1994, Colosio was assassinated during a campaign event. 1994 (directed by Diego Enrique Osorno) and Crime Diaries: The Candidate (Historia de un crimen: Colosio, directed by Hiromi Kamata and Natalia Beristáin) are, respectively, a documentary and a drama. Both series delve into the political conjuncture surrounding both Colosio's candidacy and his subsequent assassination, developing such premises in fundamentally different ways.

Hailing from a small town in the state of Sonora, Colosio undertook a successful political career within the Partido Revolucionario Institucional (Institutional Revolutionary Party, PRI), reaching the position of presidential candidate for the July 1994 elections. On March 23, he was assassinated amid the crowd in Lomas Taurinas (Tijuana, Baja California); although an alleged perpetrator was incarcerated, the investigations were muddied, the official version of the facts often contradicted evidence, and several conspiratorial theories have developed since. The main reference to Colosio in the public imaginary is the speech he delivered on the occasion of the party's 65th anniversary on March 6, 1994, widely considered the moment of rupture with the party's elite.

Reprising the political myths the postrevolutionary state has been based on and legitimized by, his apparently radical stance against corruption won the favor of the masses and stirred conflicts internal to the PRI. Colosio's assassination represents an inflection point in the Mexican electorate's political perception, as well as the embodiment of an ingrained shared sense of impotence. His death crystallized the sudden ending of the illusion that radical change was seemingly possible, haunting voters up to the present day. The image of Colosio acquired heroic configurations, as his unrealized presidency has come to embody the "México que no fue," a radically innovated Mexican state that never was and, possibly, will never be. It is a narrative discourse that has been fueled as a political myth of a predicted-yet never realized-political event (Flood 2001, 44), corresponding to an idealized conception of change as the solution to any socioeconomic problem rooted in the governing system. Whether idealized or not, Colosio and his abrupt death have marked the memories of many a Mexican citizen, as it is demonstrated by several publications collecting personal recounts of the day of the assassination (e.g. Jáquez 2004; Ochoa 2019) and on the candidate himself (e.g. Durazo 2014).

Albeit focusing on different aspects related to the assassination, both series are based on well-known theories about it and refrain from proposing original interpretations on the possible motives and actors involved in the scheme. As will be analyzed in further detail below, both products present underlying arguments and mediate the objective information they provide, based mostly on selected original footage. Critically comparing the two series, their different narrative choices and constructions of the underlying political discourse will be highlighted, as well as their relationship with the mythification of Colosio in the collective imaginary. It will be shown how the documentary series 1994despite its apparent objectivityprovides a rather biased perspective facilitating specific discourses, whereas Crime Diaries: The Candidate chooses to focus on the description of contexts the viewers would find 
more relatable. The comparison will be based on the analysis of three main themes fundamental to the reconstruction of the narrated events: the Mexican political context at the time of the assassination; Colosio's characterization and his private life; and the procedural aspects of the subsequent investigations.

\section{The political conjuncture and Colosio's rise to power}

Directed by Diego Enrique Osorno and produced by Vice Studios Latin America, documentary 1994 is composed of five episodes (whose approximate length is 50 minutes each) and was released on May 17, 2019 on Netflix. The series could come across as an expository work and yet, it has no clear argumentative focus and interpretation, nor a voice-over to guide the viewer (see Nichols 2001, 105-09). Rather, it is developed through the presentation of original footage and interviews with people directly involved in the events at the time, and it is completed by establishing drone shots marking the transition between the various segments. The talking head interviews are particularly interesting, as they provide detailed recounts of personal memories and represent an original contribution to the panorama of narratives related to Colosio. These segments are apparently set in the interviewees' homes and marked by a static medium shot within a recurrent frame composition, symmetrical and in some casesdepending on the speaker's discursive intention and place in the political hierarchy-characterized by a vague awkwardness in the interviewee (Fig. 1). The extensive sequences dedicated to interviews represent a problematic issue in the reconstruction of real events. The expository mode is recreated to emphasize the "impression of objectivity and of wellsubstantiated judgement" (Nichols
$1991,35)$ legitimizing the production's ideological stance, by means of devices that will be analyzed below. Likewise, it will be highlighted how the choice of interviewees and the space dedicated to their own reflections contribute to construct the documentary's underlying ideological discourse. Such discourse is not overt, but upon examination it can be argued that it endorses the official version of the events perpetuated by the state, constituted by justificatory strategies and circumscribed admission of corrupted practices.

Despite the stress on the conjuncture, the episodes revolve around Colosio, his career prior to the candidacy, presidential campaign, and assassination. The original footage is quite rich and covers most of the events that happened in public, as well as in the police stations and the attorney general's offices. The first two episodes are dedicated to the reconstruction of the political context of Carlos Salinas de Gortari's mandate (1988-94), as the series tries to clarify for the viewer the crisis leading to Colosio's candidacy. In that moment the party itself was divided between a more conservative group known as the "dinosaurs" and the rising faction of young innovators (as explained by politician Agustín Basave in an interview sequence in episode 1), to which Salinas himself belonged. The historical dynamics leading to this internal conflict aren't quite explained in 1994 (and neither are they in Crime Diaries: The Candidate), which might result confusing. For the occasional viewer, not knowledgeable of Mexican postrevolutionary political history, it could be difficult to grasp the continuous references to previous events and organizations; a fundamental contextualization about the party itself is missing. The central episode of 1994 is dedicated to the actual day of Colosio's assassination, while the last two episodes delve into the consequent investigations. 

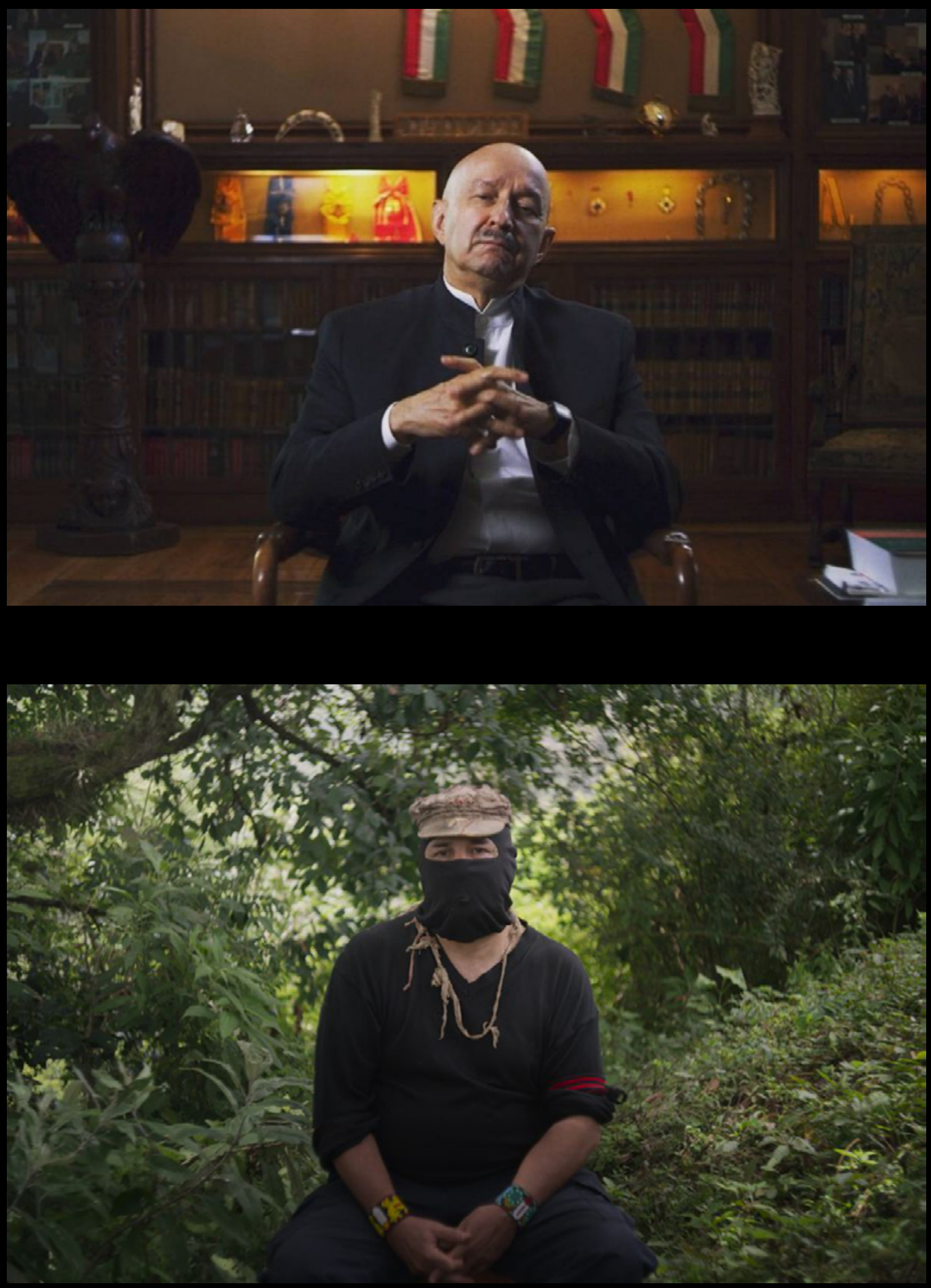

Fig. 1: The interviewees' frames: ex-president Carlos Salinas de Gortari (top), Subcomandante Galeano (bottom). 1994 (Diego Enrique Osorno, 2019). 
1994 starts with Carlos Salinas de Gortari's election as President of the Mexican Republic, as his sexennial mandate saw the development of Colosio as a relevant political actor to the point of being chosen as candidate by the incumbent president. The steps in Colosio's career are reconstructed with chronological precision, showing his rise to the direction of the party (1988-92) and then his inclusion in the Executive Cabinet as the head of the Secretaría de Desarrollo Social (SEDESOL, Secretary of Social Development). The first episode of the documentary series presents several elements that contribute to a foreboding mood and a sense of suspense peculiar to the true crime documentary genre. For example, a shade of suspicion is thrown on unchosen candidate Manuel Camacho-without any hint as to what he might be doing next in retaliation for his unfulfilled candidacy-and insisting on his apparent reconciliation with Salinas. In the following episodes, the recurrent presence of Camacho in the narrative contributes to his construction as an antagonistic figure; for example, it is shown how the politician took Colosio's place as pacifier for the conflicts in Chiapas, which-although in the series are not mentioned -in reality have never been solved. Especially in episode 2, the series delves into the issues relayed with Chiapas and the insurgence of the Ejército Zapatista de Liberación Nacional (EZLN) started on January 1,1994 . The insurgents' motives are often overlooked or minimized in the public discourse, or even depicted from a rather discriminatory perspective (Marini 2018, 79-80). Conversely, 1994 presents Subcomandante Galeano (previously known as Marcos) as one of the recurrent interviewees, giving space to the EZLN's perspective on the conflict.

Among the interviewees, a considerable screen time and space for articulation is given to Carlos

Salinas, both through footage and his own interview segments; nonetheless, his persona remains within its consolidated boundaries. It is worth recalling that Salinas's mandate has been instrumentalized by current president López Obrador, in order to support his discourse against neoliberal politics (Marini 2019, 161-62). Although Salinas's commentaries in 1994 are seemingly supposed to explain political workings, the ex-president systematically distances himself from the party elite's questionable actions, building discursively his blamelessness throughout the series. His discourse is often constructed as revealing of the covert mechanisms intrinsic to the system-showing his longstanding political power, as he "reveals because he can"-even though he does not actually reveal anything novel for the viewer with some knowledge about Mexican politics. In biopics, homosocial relationships between male figures are often privileged as "the historical figure's noteworthiness is constructed out of rivalries or supportive relationships" (Robinson 2016, 11); as highlighted by Custen, the biopic genre sees the presence of "an older figure, the bearer of conventional (sometimes limited) wisdom" (1992, 69) as a recurrent trope. In the case of 1994, several conflicting relationships are highlighted-for example those with Zedillo and Camacho, which are also described in Crime Diaries: The Candidate-whereas the main bonding connection is left to the ex-president's recounts and articulated as a mentormentee relationship. When recounting his relationship with Colosio, Salinas discursively builds his own role as a visionary and condescending patron, who championed a figure that has since been considered heroic in the collective imaginary. Nonetheless, his words reveal his commitment to those mechanisms peculiar to the party, legitimizing the "rules," their 
existence and the duty to respect them (see, among others, Castañeda 2015). As "bearing witness is a form of performance" (Bignell 2017, 64) characterized by a real person testifying to their own experience of an event, such interviews are evidently the recreation of that event from the witness's point of view rather than a neutral observation. Despite their intrinsic subjectivity, these interviews are presented as juxtaposed to original footage-whose objectivity is taken for granted, the subjective selection and editing by the documentary director notwithstanding. The absence of voiceover guidance amplifies the equation between these two types of material, despite their very different quality in terms of reliability.

Created and directed by Hiromi Kamata and Natalia Beristáin, Crime Diaries: The Candidate is a drama composed of 8 episodes (each approximately 40 minutes long) and released on March 22, 2019 on Netflix. Inspired by Colosio's case, the fictional sequences of the series are interspersed with fragments of original footage, including official speeches and news coverage. Outdoor sequences in particular are often shot with a handheld camera and provide an observational documentary feel, although the difference with the original shots is noticeable. Most of the original footage presented in the docudrama is also present in 1994, in particular the sequences depicting the assassination and those related to the alleged culprit's confessions. So-called "evidence verité" film productionusing original film footage of arrests, criminal confessions, and crime scenes (Silbey 2010,1257)—often incorporates such recordings to elicit the perception of truthiness in the viewer, recreating the apparently unmediated objectivity the documentary genre is thought to provide. As biopic docudramas do, The Candidate situates itself in a liminal space "between fiction and actuality" (Bingham 2010, 7) and it juxtaposes original footage with reenactments of such recorded events from the characters' points of view. Furthermore, to achieve a satisfactory balance between real events and the necessities of the drama format, contextual simplifications and narrative license are inevitable issues in the transposition process.

The drama opens with the sequence of the assassination, only to skip back to four months earlier and progressively reconstruct the events leading to March 23. The first episode has an evident establishing function, as most of the main characters appear in direct relation to Colosio (Jorge A. Jiménez). The candidate's renowned speech occupies a central place, alternating original footage and fictional reactions of the political elite facing his accusations and revindications (Fig. 2). The reconstruction of the political conjuncture is present, albeit often derived from personal relations. Most of the series relies on the fictional reconstruction of intimate dialogues and dynamics, loosely based on known facts and interpretations. Medium close-up shots are recurrent, used especially to depict dramatic dialogues related to the political power play, turning points in the investigations, and unexpected revelations. The docudrama evidently bridges the gap between documented facts and popular speculations by staging an imagined intimacy of well-known figures behind their public personae. The Candidate exploits a melodramatic mode often used in drama series to focus "on women characters, on the emotional and the psychological, and on moments of dramatic intensity" (Bignell 2017, 68; Bignell 2000). To do so, as it will be analyzed further on, the character of Colosio's wife Diana Laura (Ilse Salas) represents the main device through which the viewer learns about political, 

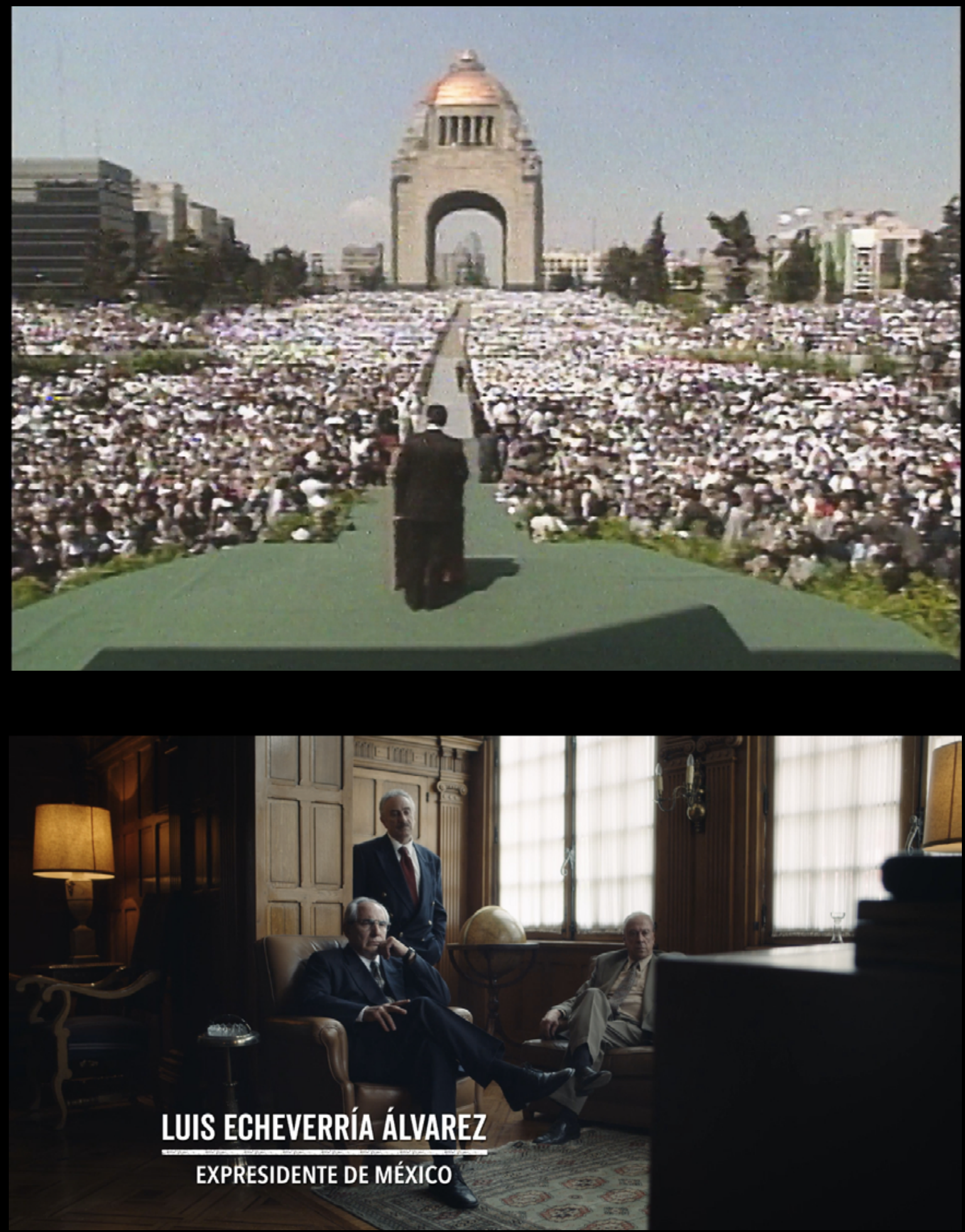

Fig. 2: The speech sequence: original footage (top), fictionalized reactions (bottom). Crime Diaries: The Candidate (Hiromi Kamata and Natalia Beristáin,

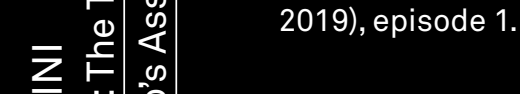

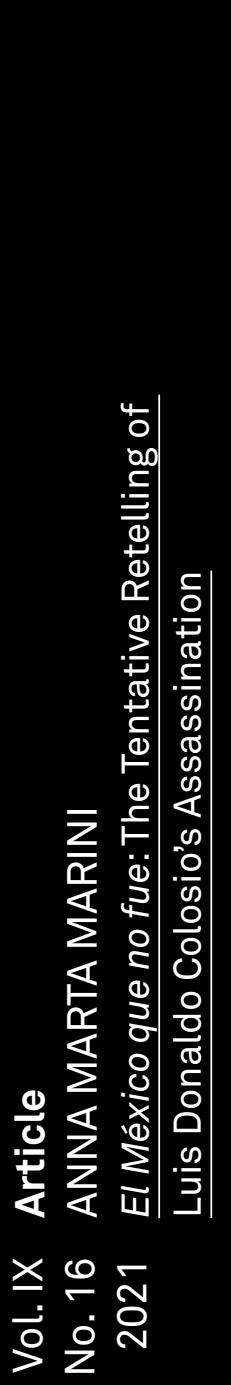


investigative, and personal details of the case.

The dynamics between Colosio and Salinas (Martín Altomaro) are reconstructed through realistic details, among which the ex-president's habit to hold extraofficial meetings with collaborators during his jogging routine in the Chapultepec forest. The occurrence actually appears as well in 1994 by means of news footage, whereas in the drama series it is exploited to insert relevant dialogues. The conflictual, antagonistic relationship between Colosio and Camacho (Enrique Arreola) is also revealed through either confrontation between the two or dialogues between other relevant political characters. In fact, Colosio's personal encounters with different actors involved in the candidacy machine seem to underline his extraneousness to the elite and, as a consequence, his rejection of its corrupt practices. Such encounters are often verging on menacing, ambiguous, or revealing of implicit power dynamics, and their mood is constructed through the use of ominous music and low-key lighting.

The docudrama blurs the boundaries between reality and fiction being, by definition, a blend of fictional form and documentary content (Rhodes and Parris 2006, 5). The fictionalization implies inevitable simplifications instrumental to the dramatization of real events, as well as the assumption of private dynamics that cannot be documented. The Candidate shows the conflict progressively raising between Colosio and Salinas after his renowned speech by means of fictional intimate dialogues. In 1994, the reconstruction of it is mostly left to Salinas's own recount and discourse-accurately structured by means of justificatory and selflegitimizing strategies - and it is not backed up by any actual documentary material. Thus, in both cases it might be complicated for the viewer to discern to what extent one representation is more accurate or reliable in this regard.

Both series stress on how Colosiobeing an experienced politician within the party-knew the imposed "rules of the game" and yet felt uncomfortable with them, obeying against his own ethos. It is worth noting that he had a very successful career in the PRI and, as his then personal assistant Alfonso Durazo declares, Colosio "entendía muy bien el rol que en cada momento le tocaba jugar" ["understood very well the role he had to play at all times"] (1994, episode 1). Nonetheless, rather than associating him with the party's questionable practices, both series use Colosio's central role in it-as well as his role in Salinas's fraudulent presidential campaign - to justify his inclination toward political innovation. Even without yielding to a hagiographic portrayal, they feed the perception that Colosio's popularity and ethos represented such a radical threat that the only possible reaction of the political system was his physical elimination.

\section{The articulation of characters and their private life}

The coordinator of Colosio's presidential campaign Igor Herrera is one of the main figures appearing in the interview sequences of 1994. While introducing the late candidate (episode 1), Herrera stresses that Colosio did not originally belong to the Mexican political oligarchy. He hailed from a modest family and his upbringing was based on a set of values that fueled his success in the eyes of the majority of the electorate, contributing to the creation of a myth around him. Both series identify as a central moment the speech he delivered on March 6 (see the footage of the complete speech at CTMMexico 2011). A critical analysis of this speech in particular reveals an intrinsic sense of social justice and 
ethical commitment (Marini 2017), an ethos that-despite the populist tinges - he seemingly abided by both through his actions and discourse. Nonetheless, Colosio's persona has been constructed in the collective imaginary based on this speech, rather than his actual actions in institutional charges. As 1994 swiftly shows through original footage (episode 2), he was first appointed to address the conflict in Chiapas and yet, he stuck to a mechanism well consolidated in the Mexican political state system. The "solution" to unrest was based on promoting limited social projects in marginalized areas - through bodies such as the SEDESOL indeed-without any actual institutional measure taken. The mythification process that arose especially after Colosio's assassination seems to neglect this kind of detail, revealing of his congruence with the power elite. The popular discourse on the candidate favors the aspects related to his discursive rupture with the "dinosaur" practices and reprobation of the consequent corruption. Such a selective approach has contributed to the propagation and consolidation of the most popular theories of the assassination, insisting on his alleged radical stance as a motive. Although the analyzed series do not reproduce the most idealized versions of Colosio's hagiographyand thus avoid presenting him as an ingenuous victim of a corrupt evil elite-they refrain from challenging such representations.

In 1994, most of the interviewees recall personal memories revolving around their intimate relationships with Luis Donaldo Colosio. From a critical perspective, a rather interesting recount is delivered by journalist Federico Arreola-author of a book on the case (2004) - who describes a few different moments of clash he had with Colosio about the ways he was conducting himself. For example, Arreola's reproaching stance on the practice of the dedazo-for which a candidate was chosen by the incumbent president, without giving equal opportunities to possible aspirants-displeased Colosio (episode 1), who justified himself by promising the practice would change during his administration. Arreola's skeptical stance on many of the government's practices is disseminated throughout 1994-for example when he criticizes the SEDESOL's action in Chiapas (episode 2). His overt critique of the political system-as well as the insistence on his own critical neutrality and journalistic ethics - can possibly lead the viewer to assume his recounts as objectively credible, supporting the perceived objectivity of the documentary series. Nonetheless, his position in reality is not as simple as it may seem. He was the journalist officially invited by the party to follow the candidate's campaign, but Arreola describes his position stressing the fact that, allegedly, Colosio chose to trust him during his rise to power on the basis of friendship and respect. Clearly Arreola is a real person, but his performance lends itself to a dramatized version of actuality, drawing on the description of emotional exchanges rather than providing details that could tarnish the credibility of his narrative.

Colosio's domestic life is present in the documentary reconstruction from the moment he is appointed as presidential candidate. The family (and his wife in particular) appears steadily from the third episode on, as Diana Laura Riojas was bound to join him on the day of the assassination. One of the interviewees introduced as a personal connection of Diana Laura is lawyer Juan Velásquez, without providing any detail on his career. Nonetheless, Velásquez has been the Salinas family's lawyer, as well as ex-president Luis Echeverría's lawyer for the trials regarding his role in the Tlatelolco 
massacre (1968). Exploring the deep involvement with such specific sections of the political elite could have shed a different light on his engagement in the case, revealing the fact that-at least at the time of Luis Donaldo's candidacy - the Colosio family was evidently not detached from said elite. Diana Laura's terminal diagnosis of pancreatic cancer is not revealed until the second half of the series - when it is referred to by Velásquez himselfalthough it is implicitly hinted at by her son in episode 1 and Salinas in episode 3. At the end of episode 4, it is revealed that Diana Laura died shortly after the substitute candidate Ernesto Zedillo was elected president. Furthermorethanks to Arreola's critical words - the viewer discovers Zedillo's changing attitudes toward the family, as he went from being known as Colosio's friend and working as the director of his presidential campaign to avoiding officially paying tribute to his wife upon her death. Zedillo's figure develops throughout the documentary series acquiring an antagonistic character and fueling the suspense, as - after all-he might as well have been involved in the assassination scheme.

The Candidate evidently backs Colosio's popular image through the fictionalized depiction of his private life and his wife's short-lived time upon his assassination. In the drama series, Diana Laura's illness represents a fundamental diegetic pivot. If in 1994 her figure is reconstructed by the witnesses' words, in The Candidate she takes things into her own hands and is the main character providing elements for the reconstruction of Colosio's life. Among the tropes exploited by biopics to deliver a fictionalized version of the subject's life, the family's role and perspective have been a recurrent choice (see Custen 1992; Bingham 2010). Especially in the case of political leaders, biopics often strive to describe the actual person behind the public persona in order to allow the viewer to "[sort] out the life of a leader" (Bingham 2010, 103), undergoing a process of understanding of the depicted events and the circumstances that brought the protagonists to their fate. A docudrama such as The Candidate offers the viewer a connection with familiar figures and events belonging to the sphere of politics and institutional history, as well as "the pleasures of identification and fantasy focused through their private experience" (Bignell 2017, 13). Thus, a sense of authenticity is constructed to elicit both recognition and identification, which can be achieved through theatrical and cinematic elements such as the actors' physical and mimic resemblance to the real figures they are playing; the use of settings and backdrops the viewer can connect to real places; and the insertion of original footage and careful editing in order to juxtapose well-known events and sequences fictionalizing the possible developments surrounding them.

In this case, the representation of Diana Laura is supported by and matched with original footage and news coverage, providing fragments of her declarations in public, as well as her personal recordings, and placing them within the fictional narrative. The intimate side of Colosio's life is made relevant right from the start, as the topic of Diana Laura's illness is brought up in the very first minutes of the first episode. His domestic environment is also shown from the beginning, albeit with a foreboding mood; during the first scene in which the Colosio family enjoys some time together, the track chosen as diegetic music is "La Culebra" (in the version played by technobanda group Banda Macho), the song that-as it will be shown by means of original footagewas played out loud in Lomas Taurinas at the moment of the assassination.

Diana Laura's role fits in well with the description of the Colosio's family 
dynamics: in the initial sequences the relationship between Luis Donaldo and Diana Laura is reconstructed as affectionate and bereft of conflict, eliciting shock and compassion in the viewer when things go awry. The focus on a more intimate depiction is evident in the representation of the party's wake as well. As it is shown in 1994 through footage, it was held in a huge hall in the PRI headquarters in presence of a wide audience; in the drama, the wake is set in a smaller, more private venue and it fosters a dialogue between Diana Laura and Colosio's father (using medium and close-up shots) [Fig. 3].

Just like 1994, The Candidate also underplays the family's connections with the political elite, although mostly for the sake of simplification. At the end of episode 5, Diana Laura discovers that she has been wiretapped, as she receives an anonymous package containing a recorder and several tapes; she then reproduces a conversation the viewer saw at the beginning of the episode. This narrative device is backed up by family friend Agustín Basave's declarations in 1994 (episode 4 ), although he recounts that she and her husband were well aware of being wiretapped before the assassination, possibly as Colosio was appointed to institutional positions. Nonetheless, the drama exploits the wiretapping issue to build on Diana Laura's frustration, disappointment, and distancing from the party. The Candidate also romanticizes her indirect involvement in the investigations, affording her an agency she didn't actually have. She hired abovementioned lawyer Juan Velásquez as her representative for the case because she was struggling with her terminal illness; her personal investigation-especially in episode 7 when she flies to Tijuana alone-is fictionalized and it comes across as unfeasible. The fictional development of her direct struggle against an overbearing political elite serves the construction of Diana Laura as a radical heroine as much as her husband was. The viewer is driven to establish a relatable connection to her character, as she seems to be the victim of a sense of impotence that is widespread among the Mexican public. Facial close-ups in key dramatic moments also help the viewer to establish an emotional connection with Diana Laura. Moreover, her character is instrumental to the introduction and consolidation of more formal investigating characters, as she contacts them in different moments to discuss a variety of matters. For its reconstruction of the investigations, The Candidate relies on real characters fictionalizing their steps, based on their known findings. Head of Tijuana Municipal Police José Federico Benítez López (Alberto Guerra) carries out his own parallel investigation, accompanied by his collaborator David Rubí Gómez (Gustavo Sánchez Parra) - who was, in reality, the head of Tijuana's special tactics group. Their clash with Federal Police local boss López Riestra (Leonardo Alonso) helps the drama in representing the corrupt side of Mexican authorities, as this latter character is fictional and created in order to simplify the threat posed to Benítez during his investigative intents. The Candidate follows Benítez as he delves into the case locally, trying at the same time to protect the family of the accused, Tijuana resident Mario Aburto (Jorge Antonio Guerrero). His investigations will eventually end abruptly with his own assassination at the end of episode 7, after being threatened by a variety of actors that seem to stand on a blurred line between authority and organized crime. The family of the accused acquires a relevant role in the drama series; as represented, they actually fought for justice and were objects of repression themselves, to the point they were forced to seek refuge in the United States where they still 


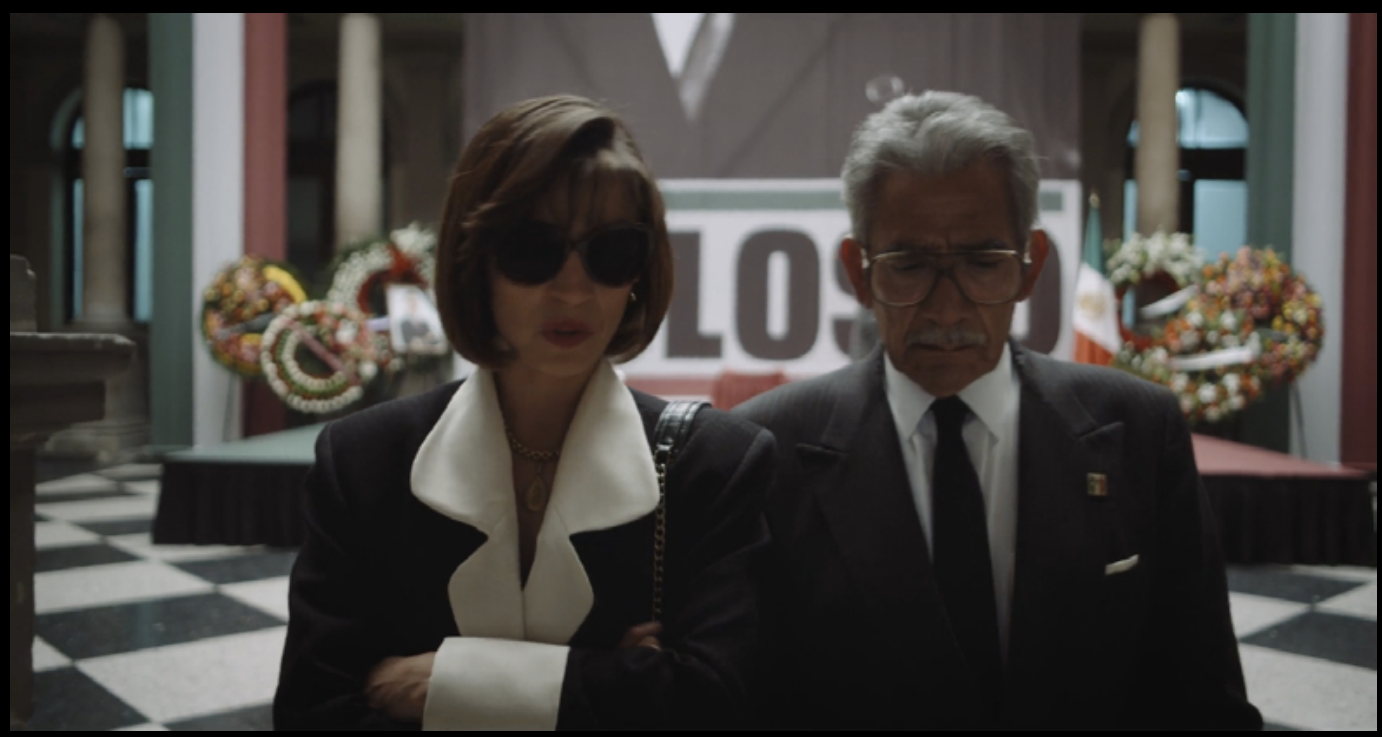

Fig. 3: Luis Donaldo Colosio's official wake. Crime Diaries: The

Candidate (Hiromi Kamata and Natalia Beristáin, 2019), episode 3.

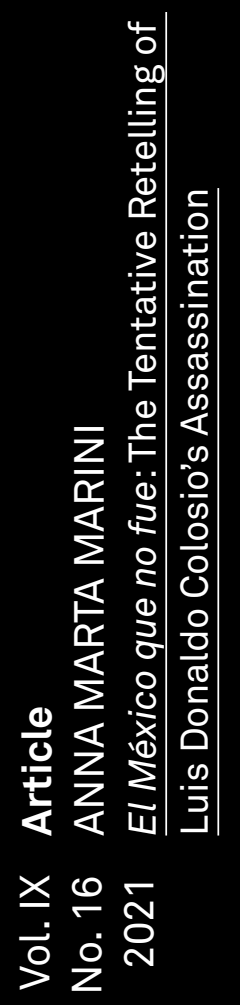


live. A thorough investigation carried out by Sánchez Ley (2017) reveals, in fact, the Aburto family's attempts to understand the true dynamics behind the incarceration of son Mario. Their effort led to recorded declarations at the time of the events, and a public request of justice addressed to current president López Obrador in March 2019 (Imagen Noticias 2019). For its part, 1994 neglects the developments of the investigations and the role that the Aburto family has played in maintaining alive the controversies related to the questionable development of the investigations.

\section{The procedural aspects of the murder investigations}

In Mexican public discourse, a popular reaction to institutionalrelated violence is the refrain "fue el Estado" ("[the culprit] was the State"), intended in a rather broad sense as the ruling political system. It is important to stress that the Mexican federal government and its local ramifications have systematically repressed - often violently - specific political, socioeconomic, and ethnic segments of the population up to the present (Marini 2020, 368-92). Aside from a few cases that have drawn international attention-such as the massacre of Tlatelolco (1968) or the disappearance of the 43 students of Ayotzinapa (2014) - the presence of state repression has been pervasive on varying levels since the establishment of the post-revolutionary state in 1917 , accompanied by a generalized violence perpetrated by the federal and local authorities (see, among many, Pérez Aguirre 2018). The most well-known cases remain somehow suspended in the collective consciousness, as the authorities never truly clarify them and the official versions of the events are characterized by evident loose ends. It is also relevant to mention that-even outside guerra sucia related contexts - the Mexican federal and local authorities have been known for violently extorting confessions.' Scrolling down comments left on almost any YouTube video mentioning the Colosio case, a considerable percentage of Mexican users claim that Carlos Salinas is the culprit, even when the video does not focus on the ex-president at all. Both series analyzed insinuate the fact that he-as well as his closest links - must have known at least something about the assassination scheme. Nonetheless, in the case of 1994 the choice to dedicate such an amount of screen time to Salinas's self-legitimizing discourse is problematic, as his commentary is clearly aimed at distancing himself from any lingering connection related to such a scheme. Despite the apparently objective stance, the director's choice seems to endorse the ex-president's personal narrative, which cannot possibly be considered as objective due to his own direct involvement in the political conjuncture leading to Colosio's assassination. The absence of documentary material contrasting or challenging his version-which is accompanied mostly by news footagedoes not provide the viewer with any tool to critically consider his words. The selection of original footage also seems to favor excerpts of public speechesrevolving around Colosio's candidacy and assassination - in which Salinas leaned toward emotional delivery, rather than evidencing his actual political and discursive shrewdness.

As mentioned before, from the first episode of the documentary Camacho is introduced as Colosio's embittered antagonist; nonetheless, it is also shown how he later distanced himself from the PRI and undertook a tentative candidacy with a small independent party. In The Candidate, the improbability of his culpability is constructed in a dialogue with Diana Laura (episode 3), in which he underlines how the dynamics unleashed 
by the assassination ruined his own political career irreparably. In 1994, substitute candidate Ernesto Zedillo is presented as the inevitable surrogate (episode 4), caught by surprise and who never wanted to be in such a position. Interestingly, analyzing footage fragments of Zedillo's official speeches provided in the documentary, his discourse and the related paralinguistic cues denote confidence and command of the situation, rather than the sense of displacement suggested by some of the documentary interviewees-including Salinas. From a critical discourse analysis point of view, the inconsistency between Zedillo's actual speech delivery and the interviewees' description of his alleged reluctant disposition is evident, and yet the documentary does not acknowledge it. Once again, through the apparently unmediated use of the interviewees' discourse, the documentary seems to endorse the official version of the events, distancing the party and its substitute candidate from possible implications in the scheme that are quite popular among the public. Conversely, The Candidate constructs Zedillo's character (Hernán del Riego) as deceptive and unpleasant from the start, and-although without leaning on any type of accusation-it insinuates in the viewer the idea that, within Colosio's entourage, he was most favored by the assassination. Sequences revolving around Zedillo are often accompanied by an ominous extra-diegetic music, low-key lighting, dark backdrops, and frames focusing on his disgruntled facial expressions. The character's lines tend to be threatening and sardonic, constructing him discursively as a shrewd politician driven by conflicts with Salinas, duplicity, and hidden purposes (see for example the dialogue with his advisor, episode 6).

The repeated employment of wellknown images connected to a historical event elicit specific interpretative patterns in the public. When the same images are exploited in popular cultural products - as both The Candidate and 1994 are - their presence "legitimates (even authorizes) the message conveyed" (Silbey 2010, 1261). Thus, their use facilitates the construction of an effective dominant narrative and its intended implications. The video capturing the moment in which Colosio was shot is very well-known by the Mexican public, and it appears in both series. The footage from the day of the assassination is reproduced in long fragments, showing the mass cheering and then freaking. The drama series adds some close-up reconstructions of the event, as well as some shots from different points of view, but the reality is in itself very effective at conveying the confused, frantic moments before and after the shooting (Fig. 4). If the insertion of such fragments in 1994 is coherent with the documentary format, in The Candidate the juxtaposition of fictional reconstructions and original footage that can be easily recognized by the Mexican audience is crucial to convey an impression of reliability and support its definition as a docudrama.

1994 reconstructs the consequent investigations mostly through news coverage, official declarations, and footage related to the accused's formal interrogations. The only witnesses that provide actual information on the case are Rodolfo Mayoral-son of one of the members of the private security employed in Lomas Taurinas-and human rights prosecutor José Luis Pérez Canchola. On the one hand, the consistent amount of original footage inserted in the procedural part contributes to a sense of frustration and incomprehension in the viewer, to an extent recreating what might have been the public feelings and impressions at the time. On the other hand, sometimes the footage fragments don't provide any additional information, contain barely intelligible dialogues-especially those 

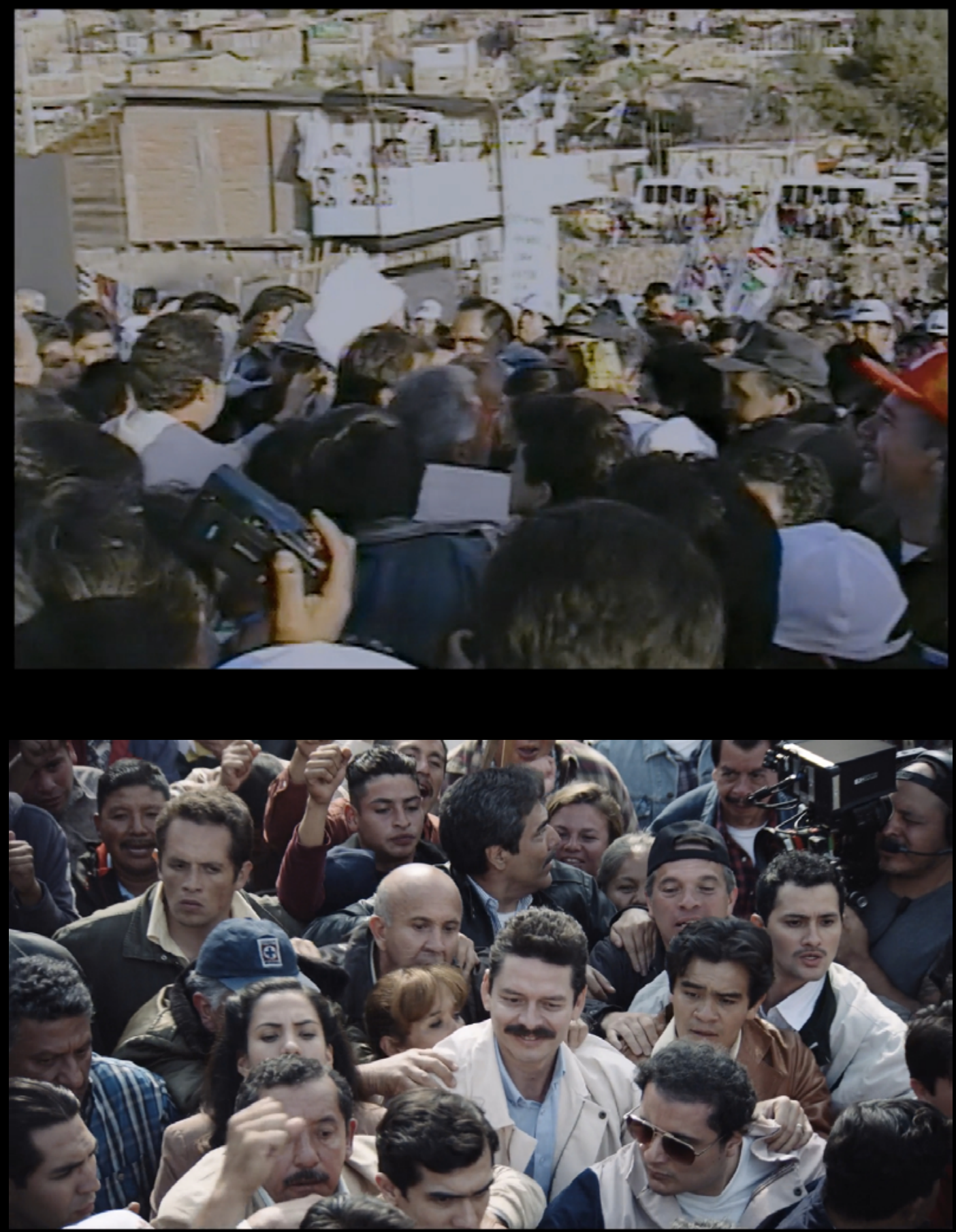

Fig. 4: Original footage of the day of the assassination (top, used by both series) and the extra shots created for The Candidate, in particular for the first episode (Hiromi Kamata and Natalia Beristáin, 2019) [bottom]. 
set at the PGR quarters (e.g. episode 4) - and in general feel redundant. These sequences are characterized by an intrinsic incongruency that can engender doubts about the motives underlying the recording itself, as it bears a quality of re-enactment. Nonetheless, the documentary lacks direction in such respects and the viewer unacquainted with the Mexican context might interpret the sequences as a stereotypical rendition of bureaucratic inefficiency. 1994 seems to rely on "evidence verité" strategies to purport objectivity by showing how abusive authorities can be-for example by means of footage in which Mario Aburto is screamed at by police officers-and yet it mostly creates a sense of alienation in the viewer that doesn't facilitate any further understanding. The extrajudiciality with which both the investigations were conducted and the political elite acted remains undisclosed, avoiding footage of serious coercion and relying on the obfuscating discourses performed by the interviewees.

In episode 4, it is shown how Miguel Montes, Supreme Court Justice in charge of the investigations, stepped down amid the public demand for clear results. As Diana Laura's lawyer Velásquez simply states in this same episode, the consequent repeated changes in investigative team complicated the contrasting narratives even further, fueling the public suspicion that a political conspiracy had taken place. The main accusations fell on Mario Aburto as the sole perpetrator of the assassination, although the authorities couldn't produce a solid motive excluding the existence of an instigator; evidence was circumstantial and legitimized by a confused ideological plot allegedly concocted by Aburto. Shortly after the election of Zedillo in July 1994, the general secretary of the party Ruiz Massieu was assassinated and
Salinas's brother was accused as instigator for many a reason; in episode 5 , the jumps between one case and the other-as well as their connectioncan be confusing for the viewer.

Albeit showing how muddied the investigations seemed to become, the documentary series doesn't place much stress on the many incongruencies. In private communications, Aburto has maintained that he had been a scapegoat (Sánchez Ley 2017) and yet, in 1994 the idea that he was the sole perpetrator remains unchallenged. Fabrication, violence, and threats against detainees and witnesses have been used systematically by the state, with the aim of weakening the popular opposition to the official version on controversial events. Such version is usually backed up by the construction of a specific institutional discourse employing recurrent strategies to shun responsibilities, legitimizing the state's response and delegitimizing the victims' voice. In recent years, two relatively well-known cases would be the disappearance of the Ayotzinapa students (2014) and the repression in Nochixtlán of the protests against the current reform on education (2016); in both cases, the state systematically proposed an evidently partial version of the facts, based on a discourse aimed at delegitimizing the protests and covering the authorities' extrajudicial response (Marini 2020). The documentary's lack of reference to the extrajudicial practices employed by authorities in the Colosio case seems to endorse-albeit not overtly-the official version. The mention of the possible participation of actors related to organized crime is also absent. The political elite's responsibilities and involvement feels like a mere expression-albeit as malicious as it gets - of political power games, somehow keeping the living protagonists unblemished by possible connections with criminal activities. 
The Candidate takes a different direction and represents the investigations on a lower level of social hierarchy rather than focusing on the power circles, tackling dynamics that are left out of 1994. The drama attempts at showing how the elite's power play affects all the social actors involved, as well as the impotence citizens can be subjected to by Mexican institutions. Ruiz Massieu's (Omar Medina) assassination is shown in the drama as well, although the events that led to it are simplified and much is left untold. In the second half of the series, the mechanisms distinctive of state terrorism strategies are evident: the threats posed to Aburto's family and community are fictionalized and yet based on testimonies and recounts (Hernández Haddad 2017; Sánchez Ley 2017), just as traces of the contradictory results of the investigations are easily accessible (PGR 1996; Aguilar Camín 2004). Episodes 4 and 5 follow the investigations carried out by Miguel Montes (Marco Treviño), dramatizing his personal relationship with Diana Laura and thus allowing for dialogues on the advancements. Once again, in The Candidate the information about the official investigations and changes in power is rendered mostly through personal conversations. The character of Diana Laura provides simplified information on the proceedings and on Colosio's feelings on the context prior to his assassination. Nonetheless, what might seem narrative license often results backed up by the testimonies provided in 1994, as well as other documentaries (among many, Magnicidio: Complot en Lomas Taurinas [Miguel Marte, 2002] and Mario Aburto: el actor - Los expedientes secretos del Caso Colosio [Mexicanos Contra la Corrupción y la Impunidad, produced in the 25 years following the events. Diana Laura's fictionalized 2019]) and recounts (e.g. Meraz 2019) initiative to briefly delve into the case herself leads her to an encounter with Aburto's family in Tijuana, as well as a contact with Municipal Police head Benítez. This diegetic construction allows the drama series to depict the assassination of Benitez as well, on the fictional premises that he was shot while going to an appointment with Diana Laura before her departure. In reality, the recounts of the shooting are muddied and the related investigations led to a swift conclusion blaming local narcotraffic gangs. Furthermore, The Candidate occasionally represents investigative journalism as well, although the theme could have been exploited more, as the violent repression of journalistsboth by organized crime and corrupt authorities - has been a critical topic in Mexico and especially in Tijuana for decades.

\section{Conclusions}

The biopic genre has often been seen as an unexciting formula, despite the critical success many a biopic film achieved through the years (Vidal in Brown and Vidal 2013, 1-32). Biopic works seem to constitute, as Dennis Bingham facetiously suggested, a "respectable genre of very low repute" $(2010,3)$, whose fundamental claim is to project specific public figures as "markers of historical significance" (Robinson 2016, 3) and, consequently, behold an intrinsic ideological discourse strictly related to the choice of the depicted figure itself.

In this case, the almost contemporary production and release of two limited series revolving around Colosio's rise to power-and consequent death - try to offer two different retellings of it, although without providing any original interpretation.

The postrevolutionary Mexican state has a long history of conspiracy, as well 
as violent repression, and consolidated discourses aimed at covering up its role in the events. Osorno's documentary series 1994 comes across as a thorough reconstruction of the political conjuncture whose public culmination was, indeed, Colosio's assassination. The effort to provide a wide and diverse range of testimonies, including powerful political actors along with selected witnesses, is tainted by the exclusion of scholarly voices and journalists not directly associated with Colosio himself. The recurrent references to the established system distinctive of the Mexican state are left unexplained. Given the international scope of the project, a concise contextualizing outline would have possibly helped the less knowledgeable viewer to grasp the significance of the information presented.

The drama Crime Diaries: The Candidate reconstructs the same crucial moments from a more intimate yet implicitly critical point of view, resorting to thorough research into the events-as it often happens with this kind of docudramas (see Paget 1990, 13-35) - and original footage. If 1994 focuses on the political plots and power relations, The Candidate shifts the focus toward Colosio's family, as well as the investigations themselves and their procedural incongruency. In conclusion, both series effectively represent the intricacy and systematic manipulations distinctive of the Mexican political oligarchy. As far as the image of Luis Donaldo Colosio is concerned, they reproduce and nuance in different ways the paradigm of the well-meaning, hard-working leader who got entangled in a ruthless system he could not possibly change-nor effectively challenge-despite his popularity among the electorate. In 1994 the idea that, on several occasions, Colosio abided by the system against his own ethos transpires through the words of witnesses; it would have been an original addition, perhaps, to explore this specific aspect of his political career. Both series fail at providing a complete outline of the conjuncture, albeit in different ways. If the drama oversimplifies the political contextcoherently with the type of productthe documentary provides details on the power dynamics at play and yet, it skips most of the actual developments in the investigation. The latter is the most problematic aspect about 1994, as it avoids acknowledging the social impact of the extrajudicial handling of the investigations, perpetuating the issue of the systematic institutional invisibilization of the victims of staterelated violence. The choice comes across as a perpetuation of the distance existing between the political elite and the population. Despite the effective representation of the intrinsic corruption, the documentary fails at revealing its consequences for the nation.

It is worth highlighting that both series rely consistently on the exploitation of "evidence verité" strategies to offer an assumedly authentic representation of the events narrated, blending original footage with documentary techniques, evident extensive research on the figures depicted, and reflecting the popularly shared imaginary of Colosio. The docudrama Crime Diaries: The Candidate exploits such rhetorical strategies distinctive of the documentary in order to persuade the audience of the validity of its representation and consequent intrinsic truthfulness, constructing a multimedial "discourse of factuality" (Paget 1990,4). The recreation of the surrounding narratives is based on their plausibility: the original footage supports fictional sequences built on recognizable locations and diegetic developments that fit the dominant narrative with which the Mexican viewers are familiar. For its part, 1994 departs from the Mexican documentary 
tradition-often characterized by social and/or educational commitment, the exposure of corrupted political power play, and an effort to retrieve the collective historical memory (Zavala 2012) - by favoring the expression of interviewees belonging to the political elite itself. The selection of original footage is made congruently with the interviewees' recounts and performance of the self, rather than providing a counternarrative based on unmediated facts. Despite the tentative retellings proposed by both series, Colosio's assassination remains depicted as a political myth revolving around a predicted event that could never take place. The belief that Mexico would have changed radically with his presidency is left untainted, possibly fueling further the popular hope that one day, somehow, a similar chance might return.

1/ In 2016, the Mexican section of the UN High Commissioner for Human Rights raised alarm about the fact that the $46 \%$ of inmates either confessed to a crime or changed their original confession under some kind of torture, threat, or aggression (Encuesta Nacional de la Población Privada de Libertad 2016, by Instituto Nacional de Estadística y Geografía 2017). The incidence of extrajudicial violence perpetrated by the state represents an issue that has been tackled with little success by several human rights organizations (as the related annual UN reports show, e.g. Convención contra la Tortura y Otros Tratos o Penas Crueles, Inhumanos o Degradantes, published by UN High Commissioner for Human Rights, July 24, 2019).

\section{References}

Aguilar Camín, Héctor. 2004. La tragedia de Colosio: Según el testimonio de sus propios actores, tal como puede hallarse en los ordenados infiernos de la fiscalía especial del magnicidio. Mexico: Editorial Alfaguara.

Arreola, Federico. 2004. Así fue. La historia detrás de la bala que truncó el futuro de México. Mexico: Editorial Alfaguara.

Bignell, Jonathan. 2000. "Docudrama as Melodrama: Representing Princess Diana and Margaret Thatcher." In Frames and Fictions on Television: The Politics of Identity within Drama, edited by Bruce Carson and Margaret Llewellyn-Jones, 17-26. Exeter, UK: Intellect.

2017. "Docudrama Performance: Realism, Recognition and Representation." In Genre and Performance: Film and Television, edited by Christine Cornea, 59-75. Manchester, UK: Manchester University Press. https://doi. org/10.2307/j.ctt1vwmg3w.9

Bingham, Dennis. 2010. Whose Lives Are They Anyway? The Biopic as Contemporary Film Genre. New Brunswick, NJ: Rutgers University Press.

Brown, Tom, and Belén Vidal. eds. 2013. The Biopic in Contemporary Film Culture. London, UK: Routledge. https://doi.org/10.4324/9780203384572

Castañeda, Jorge. (1999) 2015. La herencia: Arqueología de la sucesión presidencial en México. Mexico: Penguin Random House México.

CTMMexico. 2011. “Lic. Luis Donaldo Colosio Discurso Completo 6 de Marzo de 1994." YouTube video, 1:00:58, July 22, 2011, https://www.youtube.com/ watch?v=ZVWiMjErc-o [accessed March 17, 2021] 
Custen, George F. 1992. Bio/pics: How Hollywood Constructed Public History. New Brunswick, NJ: Rutgers University Press.

Durazo, Alfonso. ed. 2014. Colosio: El futuro que no fue. Mexico: Ediciones Proceso.

Flood, Christopher. 2001. Political Myth: A Theoretical Introduction. Revised ed. Hove, UK: Psychology Press.

Hernández Haddad, Humberto. 2017. El eslabón perdido. Mexico: Penguin Random House México.

Imagen Noticias. 2019. "AMLO recibe carta de los padres de Mario Aburto, el responsable del asesinato de Colosio."YouTube video, 1:39, March 22, 2019, https:// www.youtube.com/watch?v=yFcCbePH_28 [accessed March 17, 2021]

Instituto Nacional de Estadística y Geografía (INEGI). 2017. Encuesta Nacional de la Población Privada de Libertad 2016. Published July 31, 2017.

Jáquez, Antonio. ed. 2004. “La Pasión de Colosio," Special Issue, Revista Proceso 14 (March-April).

Marini, Anna Marta. 2017. "Análisis del discurso clave de la campaña del candidato Luis Donaldo Colosio." Department of SMeLSI, Università degli Studi di Milano, June 6. https://doi.org/10.13140/RG.2.2.19873.35686

2018. "La normalidad racista del discurso público en México y el caso de Marichuy." Iberoamérica Social 6(11): 65-83.

2019. "El Mesías Tropical: Aproximación a fenómenos populistas actuales a través del discurso de López Obrador." Chasqui Revista Latinoamericana de Comunicación 139: 151-68.

2020. "Una aproximación al terrorismo de Estado mexicano a través del análisis crítico del discurso institucional." In Estado de Excepción y Terrorismo de Estado, edited by Lisandro Cañón and César Román, 377-424. Córdoba, Argentina: Lago Editora.

Meraz, Norma. 2019. "Testimonio de Norma Meraz, confidente de Diana Laura." Revista Proceso 2212 (March): 22-24.

Nichols, Bill. 1991. Representing Reality: Issues and Concepts in Documentary. Bloomington, IN: Indiana University Press. Press.

2001. Introduction to Documentary. Bloomington, IN: Indiana University

Ochoa, Sidharta. ed. 2019. El día que le dispararon a Colosio. Antología. Mexico: Abismos.

Paget, Derek. 1990. True Stories? Documentary Drama on Radio, Screen and Stage. Manchester, UK: Manchester University Press.

1998. No Other Way to Tell It: Dramadoc/Docudrama on Television.

Manchester, UK: Manchester University Press.

Pérez Aguirre, Manuel Ernesto. 2018. "Panorama de la violencia estatal en las entidades federativas mexicanas." Revista Mexicana de Sociología 80(1): 63-114.

Procuraduría General de la República. 1996. Informe de la investigación del homicidio del licenciado Luis Donaldo Colosio Murrieta. Tomes I-IV. Mexico: Subprocuraduría para el Caso Especial Colosio. Retrieved from https://web. 
Relevantes/Casos\%20de\%20Interes/Caso\%20Colosio/Caso\%20Colosio.asp [accessed March 17, 2021]

Rhodes, Gary D., and John Parris. eds. 2006. Docufictions: Essays on the Intersection of Documentary and Fictional Filmmaking. Jefferson, NC: McFarland \& Company.

Robinson, Matthew. 2016. "Mapping the British Biopic: Evolution, Conventions, Reception and Masculinities." Doctoral dissertation, University of the West of England, Bristol.

Sánchez Ley, Laura. 2017. Aburto. Testimonios desde Almoloya, el infierno de hielo. Mexico: Grijalbo.

Silbey, Jessica. 2010. "Evidence Verité and the Law of Film." Cardozo Law Review 31(4): 1257-99. Suffolk University Law School Research Paper No. 10-23.

UN High Commissioner for Human Rights. 2019. Convención contra la Tortura y Otros Tratos o Penas Crueles, Inhumanos o Degradantes. Published July 24, 2019.

Zavala, Lauro. 2012. "El nuevo documental mexicano y las fronteras de la representación.” Revista TOMA UNO 1:25-36. 